ESJ Social Sciences

\title{
Career Development and Performance of Non-Family Employees in Selected Family-Owned Businesses in Kenya: West Kenya Sugar and Kirathimo Cereals
}

\author{
Jedida Gathenge \\ School of Business, Kenyatta University, Kenya \\ Eliud Obere, Supervisor \\ Kenyatta University, Nairobi, Kenya
}

Doi:10.19044/esj.2021.v17n15p239

Submitted: 19 April 2021

Accepted: 04 May 2021

Published: 31 May 2021

\author{
Copyright 2021 Author(s) \\ Under Creative Commons BY-NC-ND \\ 4.0 OPEN ACCESS
}

Cite As:

Gathenge J. \& Obere E. (2021). Career Development and Performance of Non-Family Employees in Selected Family-Owned Businesses in Kenya: West Kenya Sugar and Kirathimo Cereals. European Scientific Journal, ESJ, 17(15), 239.

https://doi.org/10.19044/esj.2021.v17n15p239

\begin{abstract}
Non-family employees in family organizations may face career development challenges. The study explores the impact of employee promotion, training, and assessment practices on the performance of nonfamily employees within family-owned organizations. The study applied a mixed-methods approach. The target population was from two family-owned businesses in Kenya, West Kenya Sugar, and Kirathimo Cereals. Using a cluster sampling approach, 106 participants took part in the study. The results indicated a positive and significant impact of employee training on employee performance $(\beta=1.049, \mathrm{t}=8.245, \mathrm{p}<.01)$, as well as promotion on performance $(\beta=0.813, t=5.300, p<.01)$. However, the impact of assessment practices on performance was insignificant $(\beta=0.524, \mathrm{t}=2.756, \mathrm{p}<.01)$. The study concludes that employee training and promotion practices predict the performance of non-family employees in family-owned organizations in Kenya. Hence, organizations should invest in developing non-family employees to enhance both individual staff performance and organizational productivity.
\end{abstract}

Keywords: Performance, Career Development, Non-Family Employee, Family-Owned Organizations 


\section{Introduction}

\section{Background of the Study}

The performance of employees in the family-owned organization is subject to factors beyond the conventional organization; featuring factors that are specific to the business model- such as the interaction among employees and family members (Yusof \& Puteh, 2017). The variation in performance could emanate from a range of factors, including leadership behaviors, cultural dynamics, or access to career development (Agyapong, Ellis, \& Domeher, 2016). The possible influence of career development practices on the performance of non-family employees is the focus of the current study.

Employee performance often relates to career development practices within the organization; where several elements that motivate, train, and propel employees influence the productivity of the employees in the workplace (Armstrong, 2011). Some of the components of career development include employee training, which provides learning either as individuals or in groups towards improving the productivity capabilities of the employees (Niles \& Harris-Bowlsbey, 2002). Another component of career development is assessment practices, which acts as the basis for the assessment of training needs as well as consequent decisions related to the skills-job matching (Armstrong, 2011). Career development also features opportunities for additional responsibilities, including additional or new responsibilities at work or promotions to increase the value and performance of the employee (Conger, 2002).

The current study focused on evaluating the contribution of career development to the performance of individual employees in the organization. Career development, through training activities, improves employee skills and facilitates higher productivity (Conger, 2002). However, studies addressing differences in employee characteristics as determinants of career development access and their consequent performance are lacking. Such differences are likely to occur in contexts like the family organization (Omondi, 2017). Particularly, the family-owned business has often shown differences in recruiting and promoting employees based on their relationship, or lack thereof, to the owners. This could imply that if non-family employees lack sufficient access to promotion or other development opportunities, they could also report performance limitations. Consequently, exploring this phenomenon in the context of family businesses could elaborate on the possibility of a difference in performance due to unequal access to career development opportunities.

The target organizations for this study were West Kenya Sugar Company and Kirathimo Cereals Company. The former is located in the Western town of Kakamega, while the latter is headquartered in Nairobi with operations in Kitale and Nakuru. 


\section{Statement of the Problem}

The performance of the employee often is influenced by practices in employee career development. While studies address general employee performance in the family-owned business, there are limited studies that relate the performance of the employees to their status as family members or otherwise (Njoroge, 2013; Afroz, 2018). Further, there have also been indications of the possibility that career development among non-family members in family-owned organizations is less than those targeting the family members (Brown, Lent, and Tehander (2012); Jehanzeb \& Mohanty (2018); Maung, 2019). The difference may influence employee performance among non-family members.

The purpose of this study, therefore, was to evaluate the causes and potential differences in employee performance that may exist between the family and non-family employees in the family-owned businesses based on their access to career development. Succession planning in the family business differs significantly in its focus on family or non-family employees, with managerial interest focusing on family members. (Leon, 2014). Hence, potential differences may also exist in the career development practices and performance relating to these non-family employees. Evaluating these patterns of career development should reveal any link to employee performance.

\section{Objectives of the Study General Objective}

The general objective of this study was to determine the influence of employee career development on the performance of non-family employees within selected family-owned businesses in Kenya.

\section{Specific Objectives}

The specific objectives of the study were:

i. To determine training's influence on performance among non-family employees in the family-owned businesses in Kenya

ii. To assess promotion effects on performance among non-family employees in the family-owned businesses in Kenya

iii. To identify the impact of assessment practices on employee performance among non-family employees in selected family-owned businesses in Kenya.

\section{Research Questions}

i. What is the impact of training on employee performance among nonfamily employees in the family-owned businesses in Kenya?

ii. How does promotion in family-owned organizations in Kenya affect employee performance? 
iii. What is the impact of assessment practices on non-family employee performance in selected family-owned businesses in Kenya?

\section{Literature Review Introduction}

The literature review for the study focuses on the theoretical framework, providing the theory of work adjustment as the anchoring theory of occupation and employee career development patterns, as well as the empirical literature review addressing the independent and dependent variables.

\section{Theory of Work Adjustment}

The theory of work adjustment, by Dawis and Lofquist (1984) has been postulated as perhaps one of the most carefully crafted theories of career choice and development (Patton \& McMahon, 2006). The theory focuses on the provision of a model for the conceptualization of interactions between people and their environment of work. It founds from a psychological perspective that relates ability, satisfaction, reinforcement value, and the person-environment correspondence. The person-environment correspondence is the central premise of the theory, whereby the fit is determined by the degree to which the environment satisfies the needs of the person and the person satisfies the need of the environment (Brown \& Lent, 2004).

Therefore, in the context of career development, the theory of work adjustment suggests that both the employee and the organization will adjust to meet the needs of each other. The organization strives to satisfy the needs of the employees through efforts such as achievement, advancement, activity, and social status; factors that act as reinforcers (Patton \& McMahon, 2006). The individual derives satisfaction from the presence of these factors in the business; which the business provides through engagement in opportunities for development (Wright, McMahan, \& McWilliams, 1994). At the same time, the environment benefits from satisfactoriness based on the actions of the individuals due to the full extent of the skills and abilities the employee provides (Boxall, Purcell, \& Wright, 2007). Work skills and work needs are deliberately matched through the development process, ultimately providing a beneficial balance for the organization and the employees (Barney, 1991). As long as both parties are willing to continue making these adjustments, they can continue deriving mutual benefits in the long term.

\section{Empirical Literature Review}

\section{Career Development in Family Businesses}

The family business structure is defined as one where the firm is controlled by one or more families with their involvement being perceptible 
in management and governance or the holding of capital stakes (Sharma, Chrisman, \& Gersick, 2012). Lissoni et al (2011) reported that globally, the family-owned model comprises $80 \%$ of the companies of all sizes and that about $50 \%$ of the global GDP comes from entities with this business model. In Kenya, it is estimated that about $70 \%-80 \%$ of all businesses, both large companies, and SMEs, are family-owned (Omondi, 2017). Globally, family businesses employ more than $50 \%$ of the employed population and this percentage is even greater in Kenya, exceeding 80\% (Njoroge, 2013). Differences in the management practices also produce different managerial structures, with managers of some of the family-owned firms being family members and others being non-family.

According to Miller (1996), employee career development is the provision of opportunities for employees to grow while improving performance within the organization. Human resource management, especially career development efforts, in the family-owned organization requires recognition of the special circumstances of work both for the family and non-family employees (Vani, Chandraiah, \& Prakash, 2014). The indications are that opportunities for growth and career development increase individual employee performance and the consequent capacity to align their objectives with the organizational goals (Jehanzeb \& Mohanty, 2018). The possibility of career advancement for the employee is seen as an influencer of their commitment to the organization as well as the potential for successfully contributing to improving organizational performance (Omondi, 2017).

\section{Employee Training and Performance}

Several studies have explored the relationship existing between employee training efforts within organizations and the performance of individual employees. According to Afroz (2018), employee training leads to an improvement in individual performance due to an increase in task engagement. Indications from the research are that employees are likely to improve their levels of satisfaction with the work following involvement in training programs. The outcome motivates positive performance in terms of the employee hours of productivity (Afroz, 2018). Therefore, Afroz (2018) reports a positive relationship as manifesting between employee training and patterns in employee performance. Mohamud (2014) reports similar findings with those of Afroz (2018), where employee training was found to provide the opportunity for the acquisition of new skills.

Al-Mzary, Al-Rifai, and Al-Momany (2015) also assessed the impacts of employee training on the performance of employees within organizations. From the study, indications are that employee training improves the skills of the employees, a finding similar to that of Mohamud (2014). According to Githinji (2014), employee training facilitates the achievement of improved 
employee performance through the increase in enthusiasm in the performance of work. The study reported an increase in the individual output of employees after their involvement in specific training programs that founded on their required skill areas (Githinji, 2014). At the same time, the opportunities for employee training enabled the acquisition of employee confidence, which increased their participation in the innovative efforts of the organization (Githinji, 2014; Dysvik \& Kuvaas, 2008). Consequently, the findings strongly support a positive relationship between employee training and performance. Elnaga and Imran (2013) support the position that employee training improves employee performance. The study reported that engagements in opportunities for training facilitate the closing of the gap between the required skill sets and the available skills within organizations. From the literature, there is a constant expression of the capacity of training to introduce new skills that would be otherwise lacking among the employees in the organization.

\section{Assessment Practices and Employee Performance}

Sauermann (2016) postulates the implementation of correct approaches and policies for performance management can improve the productivity of workers. The study details the value in objectivity, availability, and quality control as measures that ensure the effectiveness of employee assessment approaches in achieving employee performance (Sauermann, 2016). According to Ying-Ying (2012), however, employee assessment and performance management have a positive but insignificant relationship with the performance of employees. From the research, the indications are that proper approaches to performance management can improve employee performance. In Campbell (2008), the behavior of employees and low-level managers is dependent on the approaches to non-financial employee assessment and the incentives associated with this dimension of performance. The influence is mediated by the incentives that emanate from the outcomes of this non-financial performance assessment (Campbell, 2008).

According to van Herpen, van Praag, and Cools (2003), employee assessment influences the performance of employees owing to its improvement of employee motivation. The study indicated that the degree of positivity derived from the employee assessment system is dependent on its consistency and transparency relative to the organizational setup. Odhiambo (2015) argues that specific employee assessment practices increase the capacity for the acquisition of instrumental employee information towards the organization of strategies to improve their performance. At the same time, the employee assessment practices encourage employees that encounter the measurement and the associated outcomes.

Henri (2004) also assessed the relationship between employee assessment and the relationship with models of organizational effectiveness. 
In the secondary study, the focus is on the identification of performance measurement relationships with multiple perspectives organizational effectiveness, including the changes in employee performance (Henri, 2004). From the study, indications are that employee assessment practices determine the reported levels of organizational effectiveness (Henri, 2004). However, the study fails to give particular attention to employee performance.

\section{Promotion Opportunities and Performance}

According to Saharuddin and Sulaiman (2016), promotion and compensation have a positive influence on the working productivity of employees. The positive effect is mediated by perceived levels of employee motivation as well as the levels of job satisfaction reported among the employees. Phelan and Lin (2001) explore the impact of various promotion systems on the performance of the organization. Systems such as merit-based promotion, up or out systems, and seniority-based systems are perceived as having a different impact on the performance of individual employees as well as the entire organization.

Mustapha and Zakaria (2013) also explored the effects of job promotion opportunities on the performance of employees; reflecting results akin to Saharuddin \& Sulaiman (2016). According to the study, there is a significant and positive correlation between promotion opportunities at the workplace and the exhibition of job satisfaction among the employees. According to Abdulla, Djebarni, and Mellahi (2010), several factors come into play towards the determination of employee performance and job satisfaction; among them opportunities for promotion. The results of this study are similar to those in Mustapha \& Zakaria (2013), especially on job satisfaction mediating the effect of promotion opportunities on performance. From the research, promotion opportunities had a positive correlation with job satisfaction and job performance, albeit lower than other factors like monetary incentives and policies.

\section{Summary of Literature and Research Gaps}

According to the reviewed literature, training, employee promotion, and assessment practices as components of career development have several impacts on performance. The research, however, often focuses on the performance of the entire organization as opposed to individual employees. Besides, the literature mostly addresses employee assessment instead of assessment practices. At the same time, there is an existing gap where none of the studies assess the relationship between the practices in career development and the performance of individual employees within the family-owned organization or among non-family employees. The two study shortcomings, therefore, form the basis for the current study. 


\section{Research Methodology \\ Research Design}

This study applied descriptive research design. This facilitated the acquisition of data necessary for the generalization of findings to a larger population. This design enabled addressing of the "what" element of this study, specifically in the perspective of identification of the effect. The independent variable (career development) was measured in the study by the constructs of -employee training, assessment practices, and promotion opportunities - and how these variables influence performance. The measurement of the dependent variable was based on internal indicators of individual performance such as reducing the number of errors and the time spent on productive work within the organizations that participated in the study.

\section{Target Population and Sampling}

The target population for this study was the two companies included in the research. These companies were West Kenya Sugar and Kirathimo Cereals Co. The selection of these companies was based on both size and age. The former was established in 1940 and comprises about 2700 employees. However, only 754 employees were available for the research on account of the COVID-19 pandemic and consequent lay-off of some auxiliary staff. On the other hand, Kirathimo Cereals is a first-generation entity established in the year 2000. Its total employee base is about 300. Therefore, the target population for the study was the two organizations. This study applied the cluster sampling technique. This study applied clusters featuring the several organizations that depict this family-owned model. Therefore, potential respondents were identified among employees in various family-owned organizations of different products and sizes. The researcher then applied random sampling to select the sample size from the populations. The researcher selected participants among both family and non-family members that were part of these organizations for a fully representative sample.

Table 3-1. Population and Sample Size

\begin{tabular}{|l|l|l|}
\hline \multicolumn{1}{|c|}{ Organization } & Employee Population & Sample Size (10\%) \\
\hline West Sugar Kenya & 754 & 76 \\
\hline Kirathimo Cereals & 300 & 30 \\
\hline Total & 1054 & 106 \\
\hline
\end{tabular}

The organizations had an estimated total of 754 employees combined. Consequently, a sample size of 106 respondents was considered sufficiently representative for the completion of the study; being $10 \%$ of the target population (Mugenda and Mugenda, 2003). Nevertheless, there was an effort to ensure the number of respondents per organization matched the population. 
This meant the distribution of respondents where a tenth of the respondents was from Kirathimo Cereals, akin to the percentage of the population from this company. The remaining participants were from West Kenya Sugar, representing the larger population for the research.

\section{Data Collection Instruments and Procedure}

In this study, data was collected through the questionnaire; developed based on the specific study objectives. For this study, the questionnaire comprised of closed-ended questions taking the form of a five-point Likert scale. It also contained an open-ended question, allowing for the assessment of the emotional components or opinions of the participants.

The researcher began by seeking permission for the collection of data both from the institution and the target organizations. Emails comprised the initial communication to seek participant consent. The researcher then conducted a pilot test on ten of the prospective respondents, allowing the consequent testing for the questionnaire's reliability and validity. The questionnaires were distributed physically by the researcher. The final collection of the filled-in questionnaires was after six weeks.

\section{Data Analysis Methods}

The process involved the coding of the data and inputting it into the Statistical Package for Social Sciences (SPSS) for analysis. The study applied Pearson Correlation analysis, and simple linear regression to determine how the dependent variable (the performance of non-family employees) is influenced by the independent variables (employee training, assessment practices, and promotion).

\section{Ethical Considerations}

The confidentiality of the participants was among the issues that the researcher considered in the research process. To address this component, the researcher ensured the respondents did not provide any of their details within the questionnaire. At the same time, the researcher sought informed consent of participants in the research. Therefore, the researcher assured the participants through the questionnaire that their participation was voluntary. The questionnaire also contained information on the nature and purpose of the research. To ensure the security of the data, the researcher made sure to store the complete questionnaires in a lockable safe. This safe was only accessible by the researcher. 


\section{Research Findings \\ Response Rate}

The researcher distributed 106 questionnaires to employees within the two target organizations, West Kenya Sugar and Kirathimo Cereals. 106 questionnaires were returned. All of them had all the quantitative and qualitative areas addressed. This translated to a $100 \%$ completion rate. This made the responses received adequate to support this data analysis.

Table 4-1. Response Rate

\begin{tabular}{|l|l|l|}
\hline Questionnaire & Number & Percentage \\
\hline Complete Questionnaires & 106 & 100 \\
Incomplete Questionnaires & 0 & 0 \\
Total & $\mathbf{1 0 6}$ & $\mathbf{1 0 0}$ \\
\hline
\end{tabular}

Source: Survey Data, 2020

\section{Respondent Demographics}

In this section, details on the respondents' demographic characteristics are provided. This involves two aspects, their gender and their place as family members or non-family employees.

\section{Gender}

The study respondents were required to indicate their gender. The results show that the majority were male, with 61 (57\%) being male participants, and 45 (43\%) female participants as shown in Figure 4.1. This differential was expected, especially as there is a slightly higher number of male employees in both organizations than the female employees.

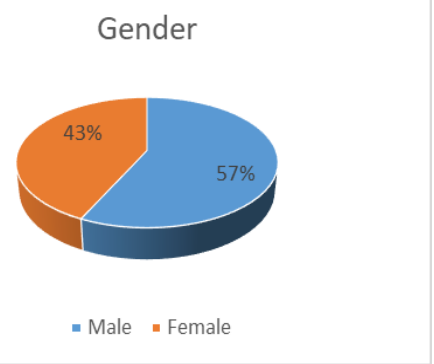

Figure 4-1. Gender Distribution Source: Survey Data, 2020

\section{Employee Status}

The respondents were also required to mark their employee status. This was expected to be between family employees and non-family employees. Twenty-nine employees were family members of the organizations' owners, while 77 respondents were non-family employees. As Figure 4.2 shows, this translated to $28 \%$ and $72 \%$ of the participants. 


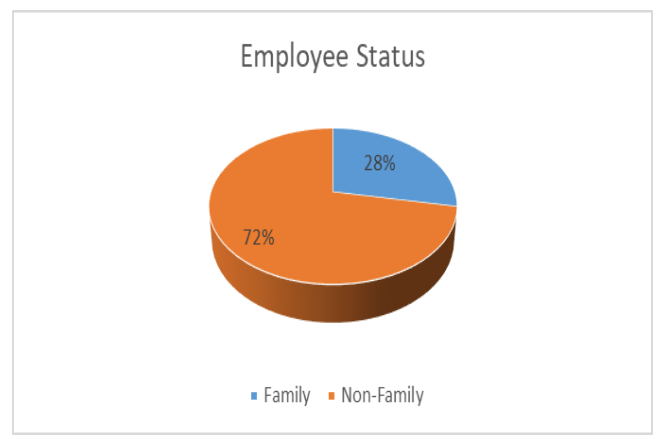

Figure 4-2. Employee Status Source: Survey Data, 2020

\section{Descriptive Statistics}

Table 4-5. Performance Descriptive Statistics

\begin{tabular}{|l|l|l|l|}
\hline & $\mathbf{N}$ & $\begin{array}{l}\text { Me } \\
\text { an }\end{array}$ & SD \\
\hline I have reduced the number of errors I make in my work & 106 & 3.47 & 4.027 \\
\hline $\begin{array}{l}\text { I have reduced the amount of time I take in completing individual } \\
\text { tasks }\end{array}$ & 106 & 3.12 & 1.093 \\
\hline I have reduced the number of days I spend away from work & 106 & 2.91 & 1.199 \\
\hline $\begin{array}{l}\text { I have reduced the number of hours I spend away from my } \\
\text { workstation }\end{array}$ & 106 & 3.02 & 1.211 \\
\hline Valid N & 106 & & \\
\hline
\end{tabular}

Source: Survey Data, 2020

The performance had a vast SD of 4.027, pointing to largely spread-out data. This aspect affirmed variations in individual performance among employees based on characteristics. The other aspects of performance had relatively clustered about the mean data. However, the perceived performance indicators were lower, but with means of 3.12 and 3.02 pointing to positive performance improvements.

\section{Correlation Analysis}

The research applied Pearson's Moment correlation at the 0.01 level of significance to evaluate the correlation between various independent variables and the dependent variable. 
Table 4-6. Correlation Analysis

\begin{tabular}{|c|c|c|c|c|c|}
\hline & Performance 1 & Training1 & PerfomAsse & Promotion \\
\hline \multirow[t]{3}{*}{$\begin{array}{c}\text { Performance } \\
1\end{array}$} & $\begin{array}{c}\text { Pearson } \\
\text { Correlation }\end{array}$ & 1 & & & \\
\hline & $\begin{array}{l}\text { Sig.(2- } \\
\text { tailed) }\end{array}$ & & .000 & .007 & .000 \\
\hline & $\mathrm{N}$ & 106 & 106 & 106 & 106 \\
\hline \multirow[t]{3}{*}{ Training1 } & $\begin{array}{c}\text { Pearson } \\
\text { Correlation }\end{array}$ & $.629^{* *}$ & 1 & & \\
\hline & $\begin{array}{l}\text { Sig. (2- } \\
\text { tailed) }\end{array}$ & .000 & & .008 & .000 \\
\hline & $\mathrm{N}$ & 106 & 106 & 106 & 106 \\
\hline \multirow[t]{3}{*}{ PerfomAsse } & $\begin{array}{c}\text { Pearson } \\
\text { Correlation }\end{array}$ & $.261^{* *}$ & $.256^{* *}$ & 1 & \\
\hline & $\begin{array}{l}\text { Sig. (2- } \\
\text { tailed) }\end{array}$ & .007 & .008 & & .001 \\
\hline & $\mathrm{N}$ & 106 & 106 & 106 & 106 \\
\hline \multirow[t]{3}{*}{ Promotion } & $\begin{array}{c}\text { Pearson } \\
\text { Correlation }\end{array}$ & $.461^{* *}$ & $.478^{* * *}$ & $.322^{* *}$ & 1 \\
\hline & $\begin{array}{l}\text { Sig. (2- } \\
\text { tailed) }\end{array}$ & .000 & .000 & .001 & \\
\hline & $\mathrm{N}$ & 106 & 106 & 106 & 106 \\
\hline
\end{tabular}

According to the results in Table 4.6, training exhibits a strong, positive, and significant relationship with performance within these family-owned organizations $(r=0.629, p<.01)$. Similarly, assessment practices showed a positive and significant correlation with the performance of employees within this organization $(r=0.261, p<.01)$. Similar results were also observed in the evaluation of the correlation between the promotion efforts and opportunities and employee performance $(r=0.461, p<.01)$. However, the data pointed to the correlation between performance and assessment, as well as between performance and promotion, to be weaker than that observed between the dependent variable and training. 


\section{Regression Analysis}

Training and Employee Performance

Model Summary between Training and Performance

Table 4-7. Model Summary between Training and Performance

\begin{tabular}{|l|l|l|l|l|}
\hline Model & $\mathrm{R}$ & R Square & Adjusted R Square & $\begin{array}{l}\text { Std. Error of the } \\
\text { Estimate }\end{array}$ \\
\hline 1 & $.629^{\mathrm{a}}$ & .395 & .389 & 1.09184 \\
\hline a. Predictors: (Constant), Training1
\end{tabular}

Table 4.7 shows the linear regression model summary between training and employee performance among staff at the two organizations. The findings show that training, as a variable, explains about $39.5 \%$ variability in employee performance within the organizations.

\section{Regression ANOVA between Training and Performance}

Table 4-8. Regression ANOVA Training and Performance

\begin{tabular}{|l|c|c|c|l|l|l|}
\hline \multicolumn{2}{|c|}{ Model } & $\begin{array}{c}\text { Sum of } \\
\text { Squares }\end{array}$ & df & Mean Square & F & Sig. \\
\hline \multirow{3}{*}{1} & Regression & 81.048 & 1 & 81.048 & 67.987 & $.000^{\mathrm{b}}$ \\
\cline { 2 - 7 } & Residual & 123.980 & 104 & 1.192 & & \\
\cline { 2 - 7 } & Total & 205.029 & 105 & & & \\
\hline \multicolumn{7}{|c|}{ a. Dependent Variable: Performance1 } \\
\hline \multicolumn{7}{|c|}{ b. Predictors: (Constant), Training1 } \\
\hline
\end{tabular}

Table 4.8 evaluates the existence of a linear relationship between training and performance. ANOVA scores below 0.050 depict a significant influence of the independent variable on the dependent and the goodness of fit of the model. Results lower than the alpha show a relationship between the variables. From the analysis of variance, there is a statistically significant linear relationship between training and performance, $(F=67.98, p<0.01)$.

\section{Regression Coefficients between Training and Performance}

Table 4-9. Regression Coefficients of Training and Performance

\begin{tabular}{|c|c|c|c|c|c|c|}
\hline \multirow{2}{*}{ Model } & \multicolumn{2}{|c|}{$\begin{array}{c}\text { Unstandardized } \\
\text { Coefficients }\end{array}$} & $\begin{array}{c}\text { Standardized } \\
\text { Coefficients }\end{array}$ & \multirow{2}{*}{ Sig. } & \\
\cline { 3 - 5 } \multicolumn{2}{|c|}{} & B & Std. Error & Beta & & \\
\hline \multirow{2}{*}{1} & (Constant) & -.019 & .396 & & -.048 & .962 \\
\cline { 2 - 7 } & Training1 & 1.049 & .127 & .629 & 8.245 & .000 \\
\hline \multicolumn{7}{|c|}{ a. Dependent Variable: Performance1 } \\
\hline
\end{tabular}

According to Table 4.9, training impacts significantly on performance among employees in family-owned organizations. Particularly, changes in one unit of training will elicit a 1.049 change in the performance of the employees $(\beta=1.049, t=8.245, p<.01)$. 
Assessment Practices and Employee Performance

Model Summary of Assessment Practices and Employee Performance

Table 4-10. Model Summary of Assessment Practices and Employee Performance

\begin{tabular}{|c|l|l|l|l|}
\hline Model & $\mathrm{R}$ & R Square & Adjusted R Square & $\begin{array}{l}\text { Std. Error of the } \\
\text { Estimate }\end{array}$ \\
\hline 1 & $.261^{\mathrm{a}}$ & .068 & .059 & 1.35544 \\
\hline \multicolumn{5}{|c|}{ a. Predictors: (Constant), PerfomAsse } \\
\hline
\end{tabular}

The table reflects the perceived summary of the linear regression model between assessment practices and employee performance. According to Table 4.10, assessment practices as a variable explains about $6.8 \%$ of the variability that manifests in performance $\left(\mathrm{R}^{2}=0.068\right)$.

\section{Regression ANOVA between Assessment and Employee Performance}

Table 4-11. ANOVA between Assessment Practices and Employee Performance

\begin{tabular}{|c|c|l|l|l|l|l|}
\hline \multicolumn{2}{|c|}{ Model } & $\begin{array}{l}\text { Sum } \\
\text { Squares }\end{array}$ & Df & Mean Square & F & Sig. \\
\hline \multirow{2}{*}{1} & Regression & 13.959 & 1 & 13.959 & 7.598 & $.007^{\mathrm{b}}$ \\
\cline { 2 - 8 } & Residual & 191.070 & 104 & 1.837 & & \\
\cline { 2 - 7 } & Total & 205.029 & 105 & & & \\
\hline \multicolumn{7}{|c|}{ a. Dependent Variable: Performance1 } \\
\hline \multicolumn{7}{|c|}{ b. Predictors: (Constant), PerfomAsse } \\
\hline
\end{tabular}

The ANOVA table evaluates the existence of a linear relationship between assessment and employee performance within these entities and the model's goodness of fit. Table 4.11 indicates the existence of a positive linear relationship between assessment and performance $(F=7.598, p<.01)$.

Regression Coefficients between Assessment and Employee Performance

Table 4-12. Coefficients between Assessment and Employee Performance

\begin{tabular}{|c|c|c|l|c|c|c|}
\hline \multicolumn{2}{|c|}{ Model } & \multicolumn{2}{|c|}{$\begin{array}{c}\text { Unstandardized } \\
\text { Coefficients }\end{array}$} & $\begin{array}{c}\text { Standardized } \\
\text { Coefficients }\end{array}$ & \multirow{2}{*}{ Sig. } & \\
\cline { 3 - 5 } \multicolumn{2}{|c|}{} & B & Std. Error & Beta & & \\
\hline \multirow{2}{*}{1} & $($ Constant) & 1.514 & .601 & & 2.519 & .013 \\
\cline { 2 - 5 } & PerfomAsse & .524 & .190 & .261 & 2.756 & .007 \\
\hline \multicolumn{7}{|c|}{ a. Dependent Variable: Performance1 } \\
\hline
\end{tabular}

The research also implemented a regression coefficient analysis to assess the level of influence that assessment practices exert over performance. From the evaluation, the study showed that, within the family-owned businesses, assessment practices positively influence employee performance. However, at the $99 \%$ level of significance, this relationship is insignificant $(\beta$ $=0.524, t=2.756, p<.01)$. 


\section{Promotion and Employee Performance}

\section{Model Summary of Promotion and Employee Performance}

Table 4-13. Model Summary of Promotion and Employee Performance

\begin{tabular}{|l|l|l|l|l|}
\hline Model & $\mathrm{R}$ & $\mathrm{R}$ Square & Adjusted R Square & $\begin{array}{l}\text { Std. Error of the } \\
\text { Estimate }\end{array}$ \\
\hline 1 & $.461^{\mathrm{a}}$ & .213 & .205 & 1.24588 \\
\hline
\end{tabular}

The table reflects the perceived summary of the linear regression model between promotion and employee performance. According to Table 4.13 , assessment as a variable explains about $21.3 \%$ of the variability that manifests in performance $\left(\mathrm{R}^{2}=0.213\right)$.

\section{Regression ANOVA between Promotion and Performance}

Table 4-14. ANOVA between Promotion and Performance

\begin{tabular}{|c|c|c|c|c|c|c|}
\hline \multicolumn{2}{|c|}{ Model } & $\begin{array}{c}\text { Sum of } \\
\text { Squares }\end{array}$ & Df & Mean Square & F & Sig. \\
\hline \multirow{2}{*}{1} & Regression & 43.598 & 1 & 43.598 & 28.088 & $.000^{\mathrm{b}}$ \\
\cline { 2 - 7 } & Residual & 161.430 & 104 & 1.552 & & \\
\cline { 2 - 7 } & Total & 205.029 & 105 & & & \\
\hline \multicolumn{7}{|c|}{ a. Dependent Variable: Performance1 } \\
\hline \multicolumn{7}{|c|}{ b. Predictors: (Constant), Promotion } \\
\hline
\end{tabular}

The ANOVA table evaluates the existence of a linear relationship between promotion and employee performance within these entities and shows the model's goodness of fit. Table 4.14 indicates the existence of a significant and positive linear relationship between promotion and performance $(F=28.088, p<.01)$.

\section{Regression Coefficients between Promotion and Performance}

Table 4-15. Coefficients between Promotion and Performance

\begin{tabular}{|c|c|c|c|c|c|c|}
\hline \multirow{2}{*}{\multicolumn{2}{|c|}{ Model }} & \multicolumn{2}{|c|}{$\begin{array}{c}\text { Unstandardized } \\
\text { Coefficients }\end{array}$} & $\begin{array}{c}\text { Standardized } \\
\text { Coefficients }\end{array}$ & \multirow[t]{2}{*}{$\mathrm{T}$} & \multirow[t]{2}{*}{ Sig. } \\
\hline & & $\mathrm{B}$ & Std. Error & Beta & & \\
\hline \multirow[t]{2}{*}{1} & (Constant) & .607 & .491 & & 1.235 & .219 \\
\hline & Promotion & .813 & .153 & .461 & 5.300 & .000 \\
\hline \multicolumn{7}{|c|}{ a. Dependent Variable: Performance 1} \\
\hline
\end{tabular}

According to Table 4.15, promotion impacts significantly on performance among employees in family-owned organizations. Particularly, changes in one unit of promotion will elicit a 0.813 change in the performance of the employees $(\beta=0.813, t=5.300, p<.01)$. 


\section{Qualitative Analysis}

Table 4-16. List of Codes and Themes from Qualitative Question (Further comments on career development and performance within the organizations)

\begin{tabular}{|c|c|c|}
\hline Themes & Codes & Excerpts \\
\hline $\begin{array}{l}\text { Family/ non-family } \\
\text { employee distinctions in } \\
\text { promotion and training }\end{array}$ & $\begin{array}{c}\text { Family employee } \\
\text { prioritization for promotion } \\
\text { and training }\end{array}$ & $\begin{array}{l}\text { "The boss' children are first } \\
\text { when promotions come up" }\end{array}$ \\
\hline & & $\begin{array}{l}\text { "It has been great, working } \\
\text { here, I have had so many } \\
\text { opportunities to interact } \\
\text { with clients and attend } \\
\text { conferences...I feel ready } \\
\text { for more" (Family member- } \\
\text { translation) }\end{array}$ \\
\hline & $\begin{array}{l}\text { Non-family employee } \\
\text { exclusion in promotion }\end{array}$ & $\begin{array}{l}\text { "If you are not in the } \\
\text { family, you will never sit } \\
\text { behind the desk } \\
\text { (Translated)" }\end{array}$ \\
\hline \multirow[t]{3}{*}{ Low performance } & $\begin{array}{c}\text { No work more than } \\
\text { necessary }\end{array}$ & $\begin{array}{l}\text { There is no need to try too } \\
\text { hard, as long as you're } \\
\text { getting paid }\end{array}$ \\
\hline & $\begin{array}{c}\text { Negative attitudes towards } \\
\text { commitment to role and } \\
\text { performance }\end{array}$ & $\begin{array}{l}\text { "Why should I work so } \\
\text { hard and I am not the } \\
\text { boss's child? Only they will } \\
\text { be the manager, not me" } \\
\text { (Translated) }\end{array}$ \\
\hline & Short-term focus on work & $\begin{array}{l}\text { You can get fired any time. } \\
\text { Just take advantage of any } \\
\text { raises or training that come } \\
\text { up }\end{array}$ \\
\hline
\end{tabular}

Despite the qualitative question offering an open platform, most of the responses pointed to an underlying disenfranchisement with the approaches to career development that target non-family members. The participants pointed to a pervasive distinction between family and non-family members, especially in decisions surrounding promotions. Specifically, the respondents reiterated that "If you are not in the family, you will never sit behind the desk" or "You can only be promoted up to supervisor, not the manager" within their comments. This was despite responses showing that most of them had received some salary increments and changes in position over the recent years. As such, while there was some consensus that the development opportunities regularly manifest, the staff felt that the chances and the benefits were more readily available to family members than the non-family employees.

On the other hand, the employees pointed to behavioral factors and attitudes that could mediate performance, regardless of exposure to development practices and opportunities. The respondents exhibited negative 
inclinations towards committing to efforts intended to demonstrate positive performance. This was particularly related to the perception that they could not progress very far within the entities, especially because senior management roles are reserved for the family members. Therefore, even as employee performance varies subject to their development, some contextual factors could reduce the responsiveness of this group of employees to the efforts. These perspectives suggested that, even as development influences performance among all employees, the effects are less pronounced for nonfamily members of these family-owned organizations.

\section{Discussion}

The study showed that employee training influences performance significantly $(\beta=1.049, t=8.245, p<.01)$. This outcome emanates from indications among the staff that exposure to training opportunities had diminished their rates of work errors and increased their commitment to internal productivity. The performance outcomes also included the number of hours spent away from work or workstation. Indications from the previous literature have supported these findings. According to Githinji (2014), employee training increases enthusiasm in the job, leading to positive performance increases and reductions in resource wastage. Besides, employee individual performance increases proportionately to training in Afroz (2018) following the acquisition of skills and consequent error reduction. As such, the outcomes of this research reflected common patterns of interactions between training and performance, exhibiting no conspicuous deviations. Hence, the focus on providing training to non-family employees within the organization underlies the performance changes they exhibit.

The findings also showed a significant relationship between promotion practices and employee performance in the organization. Notably, several employees have had promotion opportunities, even though not overwhelmingly. Regardless, the access to promotion opportunities exerts a positive and significant impact $(\beta=0.813, t=5.300, p<.01)$ on employee performance within this organization. The perspective suggests that most employees with positive performance trends expect or have had a promotion within the organization. This acts as a source of motivation or commitment to the organization. The view in the previous literature is that job satisfaction is a mediating variable in the relationship between promotion and performance. Satisfaction emanating from either the access to these promotions or the awareness of a chance for advancement perpetuates a positive response by employees, manifesting through increased productivity or performance outputs (Abdulla et al., 2011; Mustapha \& Zakaria, 2013). Hence, availing promotion opportunities to the staff within these organizations has been instrumental in determining their performance direction. 
Further, the research findings also showed a positive relationship between participation in assessment practices and performance. However, this relationship was insignificant at 99\% confidence level $(\beta=0.524, t=2.756$, $p<.01)$. The perspectives suggest that, while employee assessment practices are important, they are insignificant to eliciting changes in the performance outcomes. The indicators surrounding the variables included participating in self and peer assessment, as well as discussions on assessment practices feedback. These findings contribute to the seeming uncertainty in the literature regarding the impact of assessment practices on performance. Some studies have established that the variable predicts performance outcomes, including acting as a source of encouragement and creating transparency (van Herpen et al., 2003; Odhiambo, 2015). However, there are also indications that this practice has insignificant impacts on employee performance (Ying-ying, 2012). Perhaps further research in this area could highlight the mediating features that determine the significance of the variable in determining performance outcomes.

The theory of work adjustment by Dawis and Lofquist (1984) points out the importance of organizational-employee fit. In the theory, the fit is determined by the degree to which the environment satisfies the needs of the person and the person satisfies the need of the environment. This perspective suggests that employees make adjustments to reflect the outcomes of interventions by the organization targeting their improvement (Brown \& Lent, 2004; Patton \& McMahon, 2006). As such, the outcomes of this research accentuate deliberate adjustments by employees in response to organizational commitments, such as employee training and promotion opportunities. Performance improvements exemplify the person's satisfaction with organizational needs.

A notable aspect that emerged in the qualitative component of the study is the differentiated approach to promotion, training, and assessment that surrounds family and non-family members. The results showed that nonfamily employees are often less inclined to make an effort towards performance improvements because of perceptions of their low consideration for training opportunities relative to family staff. The themes emerging from this analytic aspect affirm a long-standing notion that employees in family firms face limitations regarding the highest levels of advancement they can accomplish if they are not family members (Njoroge, 2013; Vani et al., 2014; Omondi, 2017). Besides, the investment in training family members also seems to support this sentiment, with the long-term focus only manifesting in the family employees. However, family employees expressed sentiments to the contrary, appreciating opportunities for training and access to promotion opportunities. 
As such, the results showed distinct inclinations towards the positive performance changes of employees following an engagement in training and promotion efforts. The relationship suggested that investments in advancing or educating staff will increase their productivity efforts within the firm. Distinctions within the qualitative data suggested that family members also experience favorable conditions surrounding both promotion and training. These inclinations highlight a differential in the performance of the staff, supported by the quantitative evidence indicating the correlations between performance and these variables. Consequently, the differences in commitment to training and promotion by the organization targeting nonfamily employees may result in performance limitations within this group of staff.

\section{Conclusion}

Based on the study findings, several conclusions emerge from the current research. Training was found to have a significant influence on the performance of individual employees. Based on these findings, it can be concluded that when organizations put in place mechanisms and budget for employee training it likely to contribute significantly to the performance of those employees leading to improved organization performance. Promotion was also found to have a positive and significant impact on employee performance. Based on the findings, it can be concluded that when organizations set systems for promotion, employee performance will increase significantly. The research conclusion is that assessment practices do not necessarily influence the performance of non-family employees and organizations may not have to vary them in pursuit of these employee performance improvements. Based on the findings, it can be recommended that the family-owned businesses should establish promotion systems and set aside budgets to train both family-related and not family-related employees.

\section{Recommendations for Practice}

The primary recommendation is that family-owned organizations in Kenya should actively invest in employee training targeting non-family employees. The data supports the view that advances in employee training should enhance performance outcomes.

It is also recommended that the family-owned organizations in Kenya pursue strategies for promoting non-family employees. The focus will play a crucial role in sustaining positive performance within the family-owned organizations in Kenya. 


\section{Suggestions for Further Research}

Based on the outcomes of the current study, it is recommended that future research engages in a more targeted pursuit of family-owned organization practices in career development and their effect on performance. Future research should employ more organizations in the Kenyan context, allowing the evaluation of the impact of developmental efforts on performance as well as the comparison between companies based on their practices. A larger sample would provide a framework for evaluating and comparing companies with a higher number of non-family employees reporting developmental efforts against those without such investments, and the resulting performance patterns.

\section{References:}

1. Abdulla, J., Djebarni, R., \& Mellahi, K. (2011). Determinants of job satisfaction in the UAE: A case study of the Dubai police. Personnel Review, 40(1), 126-146.

2. Afroz, N. N. (2018). Effects of Training on Employee Performance A Study on Banking Sector, Tangail Bangladesh. Global Journal of Economics and Business, 4(1), 111 - 124.

3. Agyapong, A., Ellis, F., \& Domeher, D. (2016). Competitive strategy and performance of family businesses: moderating effect of managerial and innovative capabilities. Journal of Small Business \& Entrepreneurship, 28(6), 449-477.

4. Al-Mzary, M. M., Al-rifai, A., \& Al-Momany, M. O. (2015). Training and its Impact on the Performance of Employees at Jordanian Universities from the Perspective of Employees: The Case of Yarmouk University. Journal of Education and Practice, 6(32), 128-41.

5. Armstrong, M. (2011). Armstrong's Handbook of Strategic Human Resource Management. Kogan Page Publishers.

6. Barney, J. B. (1991). Firm resources and sustained competitive advantage. Journal of Management, 17, 99-120.

7. Boxall, P. F., Purcell, J., \& Wright, P. M. (2007). The Oxford handbook of human resource management. Oxford: Oxford Handbooks.

8. Brown, S. D., \& Lent, R. W. (2004). Career development and counseling: Putting theory and research to work. New York: John Wiley \& Sons.

9. Brown, S., Lent, R., Telander, K., \& Tramayne, S. (2012). Social cognitive career theory, conscientiousness, and work performance: A meta-analytic path analysis. Journal of Vocational Behavior, 79(1), 8190. 
10. Campbell, D. (2008). Nonfinancial Performance Measures and Promotion-Based Incentives. Journal of Accounting Research, 46(2), 297-326.

11. Conger, S. (2002). Fostering a career development culture: Reflections on the roles of managers, employees, and supervisors. Career Development International, 7(6), 371-375.

12. Dawis, R. V., \& Lofquist, L. H. (1984). A psychological theory of work adjustment: An individual-differences model and its applications. University of Minnesota Press.

13. Dysvik, A., \& Kuvaas, B. (2008). The relationship between perceived training opportunities, work motivation, and employee outcomes. International Journal of Training and Development, 12(3), 138-158.

14. Elnaga, A., \& Imran, A. (2013). The Effect of Training on Employee Performance. European Journal of Business and Management, 5(4), 136-47.

15. Githinji, A. (2014). Effects of training on employee performance: a case study of United Nations Support Office for the African Union Mission in Somalia. Doctoral dissertation: United States International University-Africa.

16. Henri, J. (2004). Performance measurement and organizational effectiveness: Bridging the gap. Managerial Finance, 30(6), 93-123.

17. Jehanzeb, K., \& Mohanty, J. (2018). Impact of employee development on job satisfaction and organizational commitment: Personorganization fit as moderator. International Journal of Training and Development, 22(3), 171-191.

18. Leon, T. M. (2014). Factors Hindering Family Business Succession Planning in Kenya: The Case of Clearing and Forwarding Business in Nairobi County, Nairobi Town. Doctoral dissertation: United States International University-Africa.

19. Lissoni, J., Pereira, M., Almeida, M., \& Serra, F. (2011). Family Business: how family and ownership shapes business professionalization. Review of Business Management, 12(37), 464479.

20. Maung, K. M. (2019). Is Career Development Essential for Job Satisfaction and Employee Retention? The 6th International Postgraduate Student Colloquium (pp. 30-42). IPSC.

21. Mohamud, A. (2014). The effect of training on employee performance in Public Sector Organization in Kenya: The case of NHIF Machakos Country. University of Nairobi: Master Thesis.

22. Mugenda, O. M. \& Mugenda, A. G. (2003). Research methods: Quantitative and qualitative Approaches. Nairobi: African Centre for Technology Studies 
23. Mustapha, N., \& Zakaria, Z. C. (2013). The Effect of Promotion Opportunity in Influencing Job Satisfaction among Academics in Higher Public Institutions in Malaysia. International Journal of Academic Research in Business and Social Sciences, 3(3), 20-27.

24. Niles, S. G., \& Harris-Bowlsbey, J. (2002). Career development interventions in the 21st century. Upper Saddle River, NJ: Merril Prentice Hall.

25. Njoroge, C. N. (2013). The effects of family-owned business on employee advancement: A case study of Nakumatt Holdings Limited. International Journal of Business and Commerce, 4(6), 1-44.

26. Odhiambo, E. (2015). The Effect of Performance Management Practices on Employee Productivity A Case Study of Schindler Limited. United States International University-Africa: Doctoral dissertation.

27. Omondi, D. (2017). Success and succession: Five characteristics of a good family business. Retrieved October 25, 2018, from https://www.standardmedia.co.ke/article/2001255095/success-andsuccession-five-characteristics-of-a-good-family-business

28. Patton, W., \& McMahon, M. (2006). Career Development and Systems Theory: Connecting Theory and Practice. New York: Sense Publishers.

29. Phelan, S., \& Lin, Z. (2001). Promotion systems and organizational performance: A contingency model. Computational \& Mathematical Organization Theory, 7(3), 207-232.

30. Saharuddin, \& Sulaiman. (2016). The Effect Of Promotion And Compensation Toward Working Productivity Through Job Satisfaction And Working Motivation Of Employees In The Department Of Water And Mineral Resources Energy North Aceh District. International Journal of Business and Management Invention, $5(6)$.

31. Sauermann, J. (2016). Performance measures and worker productivity. Sweden: Stockholm University.

32. Sharma, P., Chrisman, J., \& Gersick, K. (2012). 25 years of family business review: reflections on the past and perspectives for the future. The Family Business Review, 25(1), 5-15.

33. van Herpen, M., van Praag, C. M., \& Cools, K. (2003). The Effects of Performance Measurement and Compensation on Motivation. Amsterdam and Rotterdam: Tinbergen Institute.

34. Vani, R., Chandraiah, M., \& Prakash, C. (2014). Family Business Management in Small and Medium Enterprises at Nellore District. International Journal of scientific research and management (IJSRM), $2(8), 1249-1266$. 
35. Wright, P. M., McMahan, G. C., \& McWilliams, A. (1994). Human resources and sustained competitive advantage: a resource-based perspective. International journal of human resource management, 5(2), 301-326.

36. Ying-ying, Z. (2012). The Impact of Performance Management System on Employee performance. Master Thesis.

37. Yusof, S. A., \& Puteh, F. (2017). Favoritism and Job Performance in Family-Owned Business: Effect of Leadership Style. International Social Sciences Academic Conference (ISSAC) (pp. 18-43). ISSAC. 